\title{
Versatile Oxide Films Protect FeCrAl Alloys Under Normal Operation and Accident Conditions in Light Water Power Reactors
}

\author{
RAUL B. REBAK $\oplus^{1,2}$ \\ 1.—GE Global Research, Schenectady, NY 12309, USA. 2.—e-mail: rebak@ge.com
}

\begin{abstract}
The US has currently a fleet of 99 nuclear power light water reactors which generate approximately $20 \%$ of the electricity consumed in the country. Near $90 \%$ of the reactors are at least 30 years old. There are incentives to make the existing reactors safer by using accident tolerant fuels (ATF). Compared to the standard $\mathrm{UO}_{2}$-zirconium-based system, ATF need to tolerate loss of active cooling in the core for a considerably longer time while maintaining or improving the fuel performance during normal operation conditions. Ferritic iron-chromium-aluminum $(\mathrm{FeCrAl})$ alloys have been identified as an alternative to replace current zirconium alloys. They contain Fe (base) $+10-22$ $\mathrm{Cr}+4-6 \mathrm{Al}$ and may contain smaller amounts of other elements such as molybdenum and traces of others. $\mathrm{FeCrAl}$ alloys offer outstanding resistance to attack by superheated steam by developing an alumina oxide on the surface in case of a loss of coolant accident like at Fukushima. FeCrAl alloys also perform well under normal operation conditions both in boiling water reactors and pressurized water reactors because they are protected by a thin oxide rich in chromium. Under normal operation condition, the key element is $\mathrm{Cr}$ and under accident conditions it is $\mathrm{Al}$.
\end{abstract}

\section{INTRODUCTION}

Worldwide, the generation of electric power has several sources of energy that can be grouped as: (1) fossil fuels (coal, petroleum and natural gas), (2) nuclear and (3) renewable (wind, solar, hydroelectric, geothermal, biomass, etc.) sources. Figure 1 shows that the world energy consumption in the next two decades will be still dominated $(\sim 80 \%)$ by the burning of fossil fuels (liquid, gas and coal). Nuclear energy represents only $6 \%$ of the energy consumed worldwide. In the USA, $30 \%$ of the consumed natural gas is used to generate about $20 \%$ of electrical power produced in the country. On the other hand, $100 \%$ of the nuclear energy produced is used to generate electricity. This nuclear electricity also represents about $20 \%$ of all the electrical power produced in the country. The president of the Nuclear Energy Institute in the US said that one of her top priorities is to ensure the continuous "safe, reliable operation of the US commercial nuclear reactors" to avoid their premature retirement, which would be replaced by the burning of more natural gas, increasing the emissions of greenhouse gases. ${ }^{2}$ Currently, there are 99 operating power reactors in the US, 34 boiling water reactors (BWR) and 65 pressurized water reactors (PWR). ${ }^{3}$ Figure 2 shows in which year these power reactors were connected to the grid, affirming that $89 \%$ of the current reactors are at least 30 years old and $45 \%$ of the reactors are at least 40 years old. Only one new reactor was connected to the grid in the last 20 years. Currently, four new reactors are under construction in the USA. The existing nuclear power plants (NPP) in the USA are an aging infrastructure, which are investing a bare minimum in upgrades and maintenance. ${ }^{4}$ It is important to make these NPP safer in their operation for the remaining of their useful life.

After the Fukushima NPP black-out following the tsunami on March 2011, the international community has been dedicated to finding a fuel configuration that will be more resistant to a loss of coolant accident (LOCA) than the existing zirconium/ $\mathrm{UO}_{2}$ pellets. The massive building explosions at the 


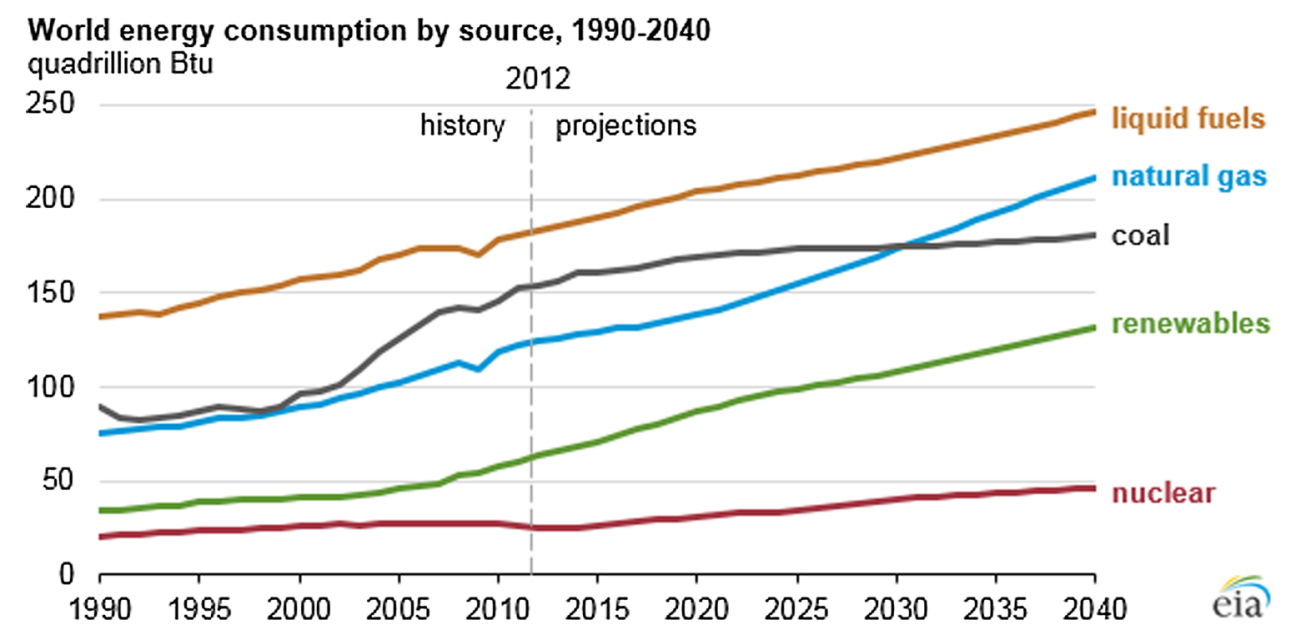

Fig. 1. World energy consumption by fuel (US Energy Information Administration 2016). Reproduced with permission from Ref. 1.

Fukushima plant were caused by the ignition of hydrogen gas formed by the fast-exothermic reaction of zirconium with water (or steam).

$$
\mathrm{Zr}+2 \mathrm{H}_{2} \mathrm{O}=\mathrm{ZrO}_{2}+2 \mathrm{H}_{2}+\text { Heat }
$$

There is currently an international research effort to delay the generation of hydrogen gas and to expand the coping time allowed for quenching or cooling the reactor after a severe LOCA. There are several proposals on how to design an accident tolerant fuel (ATF) or an advanced technology fuel (ATF) that will permit for a safer operation of the existing light water reactors. ${ }^{5,6}$ The ATF proposals include the use of iron-chrome-aluminum ( $\mathrm{FeCrAl}$ ), silicon carbide ( $\mathrm{SiC}$ ), and coated zirconium or molybdenum (Mo) claddings. $\mathrm{FeCrAl}$ is the concept that would provide the fastest implementation for the safe operation of the remaining NPP for another 40 years. $^{7}$ The proposed ATF configuration will use the current $\mathrm{UO}_{2}$ fuel clad with a thin wall (less than $0.5 \mathrm{~mm}$ thick) FeCrAl tube. Eventually, other fuels such as uranium silicide may be industrially developed for the FeCrAl cladding.

\section{Oxidation Behavior of FeCrAl}

One of the requirements for ATF from the US Department of Energy is that the cladding must perform as well as or better than zirconium under normal operation conditions and much better than zirconium under severe accident conditions. ${ }^{8}$ That is, under normal operation conditions, the cladding must do well in high-purity water at $288^{\circ} \mathrm{C}$ for BWRs and at $330^{\circ} \mathrm{C}$ for PWRs. The water may contain dissolved hydrogen for corrosion control. Under accident conditions, the cladding must do well in superheated steam at $1200^{\circ} \mathrm{C}$ or higher temperatures. That is, under a LOCA situation, the cladding may not be able to oxidize through the wall for several hours, keeping its geometry intact for quenching operations with fresh water.

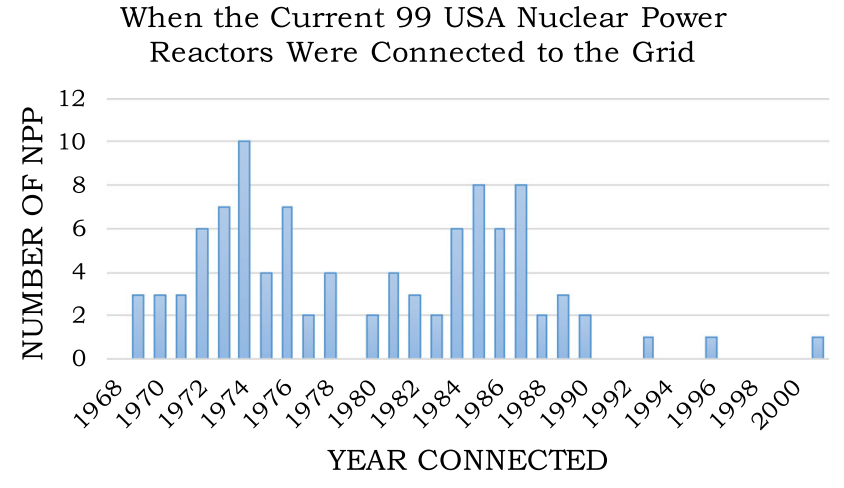

Fig. 2. The age of the operating NPP reactors in the USA. Reproduced with permission from Ref. 3.

The composition of the $\mathrm{FeCrAl}$ alloys considered could cover the following range: Fe-based, plus 12 21 mass percent (\%) of $\mathrm{Cr}$, plus $4-6 \%$ Al plus $2-3 \%$ Mo, with parts per million level of other elements such as yttrium, hafnium, zirconium, etc. Some $\mathrm{FeCrAl}$ alloys are made by powder metallurgy (e.g., APMT) and others by traditional melting, casting and forging (e.g., C26 M and Aluchrom 418 YHf).

\section{FeCrAl Behavior Under Normal Operation Conditions NPP}

Coupons of FeCrAl APMT (powder metallurgy $\mathrm{Fe}+21 \mathrm{Cr}+5 \mathrm{Al}+3 \mathrm{Mo}$ ) were immersed for 1 year in high-temperature, high-purity $18 \mathrm{M} \Omega$ water (Table I) and the mass (weight) change was monitored as a function of the immersion time.

The water conditions in Tables I and II are simulated conditions to study the effect of either oxygen or hydrogen. It is not meant to represent actual plant conditions. Figure 3 shows the mass change for APMT coupons tested in $288^{\circ} \mathrm{C}$ highpurity water containing either excess oxygen or excess hydrogen (Table I). Under oxidizing conditions, the coupons gain mass due to the formation of 
Table I. Three testing conditions for APMT

\begin{tabular}{|c|c|c|}
\hline Autoclave & Test conditions, 1 year immersion & Tested coupons \\
\hline $2584 \mathrm{~S}-2$ & Simulated PWR, high-purity water, $3.75 \mathrm{ppm}_{2}, 330^{\circ} \mathrm{C}$ & G21, G22 \\
\hline $2584 \mathrm{~S}-5$ & Simulated BWR, hydrogen chemistry $\left(0.3 \mathrm{ppm} \mathrm{H}_{2}\right), 288^{\circ} \mathrm{C}$ & $\mathrm{G} 23, \mathrm{G} 24$ \\
\hline 2584 S-6 & Simulated BWR, normal chemistry $\left(1 \mathrm{ppm} \mathrm{O}_{2}\right), 288^{\circ} \mathrm{C}$ & G25, G26 \\
\hline
\end{tabular}

Table II. Three testing conditions for APMT

\section{Test conditions, 1 year immersion}

Simulated PWR, high-purity water, $3.75 \mathrm{ppm} \mathrm{H}_{2}, 330^{\circ} \mathrm{C}$

Simulated BWR, hydrogen chemistry $\left(0.3 \mathrm{ppm} \mathrm{H}_{2}\right), 288^{\circ} \mathrm{C}$

Simulated BWR, normal chemistry $\left(1 \mathrm{ppm} \mathrm{O} \mathrm{O}_{2}\right), 288^{\circ} \mathrm{C}$

\section{Oxide films on the surface}

Single layer, Cr-Rich, 10-100 nm thick

Single layer, Cr-Rich, 100-120 nm thick

Double layer, total 150-180 nm thick,

external layer is Fe- and Cr-rich and

internal layer is Cr-rich and only 10-15 nm thick

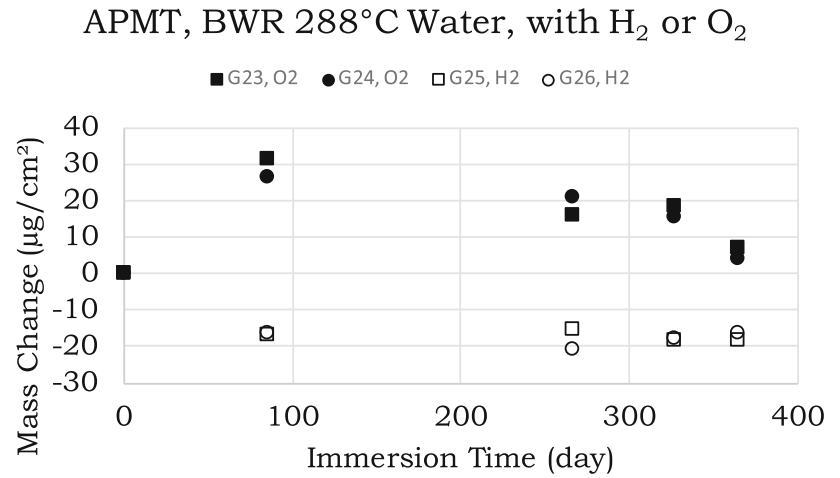

Fig. 3. Mass change versus immersion time for APMT coupons exposed at $288^{\circ} \mathrm{C}$ water with dissolved $300 \mathrm{ppb}$ hydrogen or $1000 \mathrm{ppb}$ dissolved oxygen.

thicker dual layer oxide on the surface. As the immersion time progressed, the mass gain became smaller because of the formation of a protective inner layer of chromia. The external oxide may slowly dissolve in the oxygenated water. Under hydrogen conditions, the coupons lose initially some mass, but after a single layer chromia layer forms on the coupon surface, the mass loss is stabilized.

Figure 4 shows comparatively the mass loss between the BWR $\left(288^{\circ} \mathrm{C}\right)$ and PWR $\left(330^{\circ} \mathrm{C}\right)$ hydrogenated environments. The mass loss was higher in the higher PWR temperature environment.

Figure 5 and Table II shows the characteristics of the oxides which form naturally on a FeCrAl APMT material exposed to simulated light water reactor environments. The chromium-rich oxides act as a barrier for the further dissolution of the material as shown by the low mass changes on the coupons (Figs. 3 and 4). The results presented here suggest that $\mathrm{FeCrAl}$ APMT has excellent environmental resistance characteristics under normal operation for both BWR and PWR coolants. There is no need to

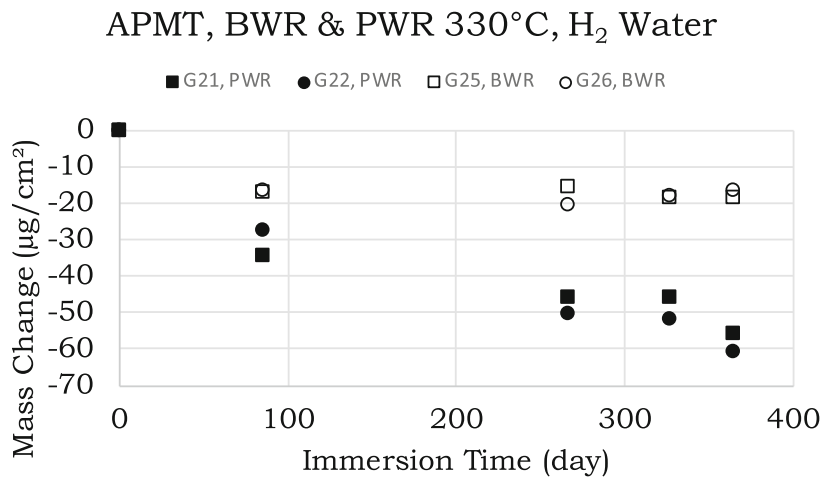

Fig. 4. Mass change versus immersion time for APMT coupons exposed in $288^{\circ} \mathrm{C}$ water with $300 \mathrm{ppb}$ dissolved hydrogen or $330^{\circ} \mathrm{C}$ water with $3.75 \mathrm{ppm}$ dissolved hydrogen.

change the water chemistry of the coolants since $\mathrm{FeCrAl}$ is compatible with the current water chemistries in light water reactors.

\section{FeCrAl Behavior Under LOCA and Severe Accident Conditions of NPP}

The main reason $\mathrm{FeCrAl}$ alloys have been selected for ATF cladding is because they have a superior oxidation resistance in superheated steam in the event of LOCA or a severe accident. Chromium provides protection against oxidation in air or in steam to all stainless steels and $\mathrm{FeCrAl}$ alloys. As the temperature increases beyond $1000-1100^{\circ} \mathrm{C}$, chromium does not effectively protect these alloys due to the evaporation of $\mathrm{Cr}_{2} \mathrm{O}_{3}$ in the environment. Beyond $1100^{\circ} \mathrm{C}$, the alloys must contain approximately $4-6 \%$ Al to offer protection. The way the $\mathrm{FeCrAl}$ alloys work is by the initial formation of a $\mathrm{Cr}_{2} \mathrm{O}_{3}$ oxide on the surface. As the temperature increases, a continuous thin alumina layer $\left(\mathrm{Al}_{2} \mathrm{O}_{3}\right)$ develops underneath the $\mathrm{Cr}_{2} \mathrm{O}_{3}$ film. Eventually, 


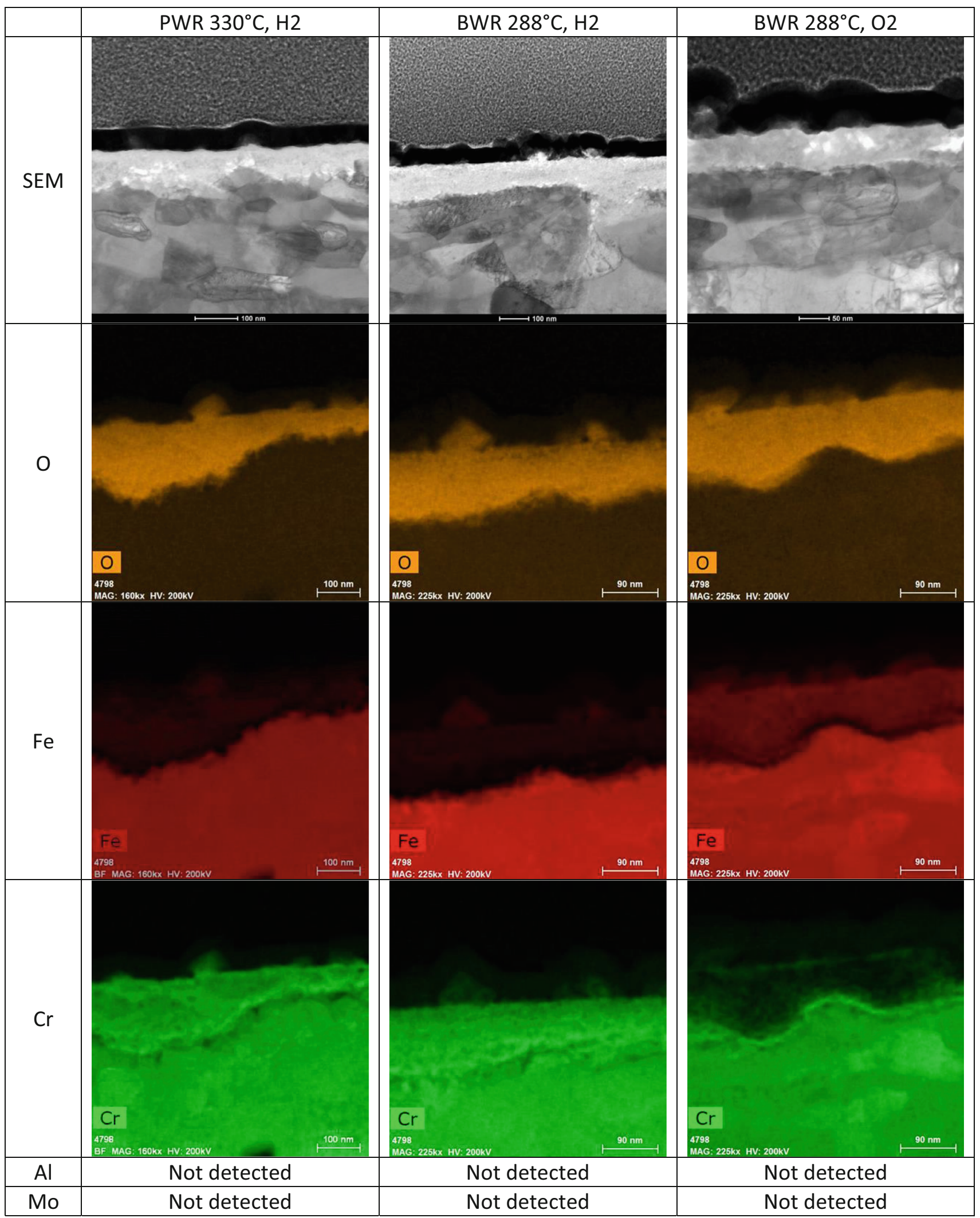

Fig. 5. Composition of the oxide film formed on the surface of APMT exposed to $330^{\circ} \mathrm{C}$ and $288^{\circ} \mathrm{C}$ water with hydrogen and $288^{\circ} \mathrm{C}$ water with oxygen. Chromium oxide always develops. 
the $\mathrm{Cr}_{2} \mathrm{O}_{3}$ oxide evaporates and the alumina layer protects the material up to its melting point of approximately $1500^{\circ} \mathrm{C}$. The combined synergistic action between $\mathrm{Cr}$ and $\mathrm{Al}$ in $\mathrm{FeCrAl}$ at very high temperatures has been known for almost a century. Figure 6 shows that, when an $\mathrm{FeCrAl}$ APMT tube was exposed to steam at $1200^{\circ} \mathrm{C}$ for $4 \mathrm{~h}$, it developed an approximately $1-\mu \mathrm{m}$-thick oxide which was pure alumina (it did not contain $\mathrm{Cr}, \mathrm{Fe}$ or $\mathrm{Mo}$ ). $\mathrm{FeCrAl}$ alloys such as APMT generally contain small amounts (less than 1\%) of rare earth elements that may help peg the protective oxide to the alloy substrate. The FeCrAl producers such as Sandvik for APMT may sell the alloy in the pre-oxidized condition. Figure 6 shows that a pre-oxidized strip of APMT also contains an approximately $0.5-\mu \mathrm{m}-$ thick alumina layer on the surface formed by exposure to air at $1050^{\circ} \mathrm{C}$ for $8 \mathrm{~h}$. The oxide formed at $1050^{\circ} \mathrm{C}$ seems to contain residual amounts of $\mathrm{Cr}$ on its outer layer.

It was shown in this work that, when freshly fabricated specimens of $\mathrm{FeCrAl}$ alloys are exposed to $\sim 300^{\circ} \mathrm{C}$ water, they develop a protective $\mathrm{Cr}_{2} \mathrm{O}_{3}$ oxide on the surface. Similarly, if these freshly fabricated specimens are exposed to $>1000^{\circ} \mathrm{C}$ steam or air, they form a protective alumina on the surface. Figure 7 shows schematically the oxide development in both scenarios (normal operation or accident) described. A pre-oxidation treatment may be considered for FeCrAl tubes since the presence of an alumina layer will act as a barrier for tritium release into the coolant.

Two questions are repeatedly asked about the oxidation behavior of $\mathrm{FeCrAl}$.

1. After the FeCrAl cladding is in high temperature water for several months, with a $\mathrm{Cr}$ oxide on its surface (Table II), would it be able to develop a protective alumina layer on the surface in the case of an accident?

2. If a pre-oxidation treatment is applied to the FeCrAl tube cladding, what happens to the alumina layer in the OD of the tube in contact with the water? Does it dissolve? Would a $\mathrm{Cr}$ oxide be able to develop on the surface (Table II) after the alumina dissolves?

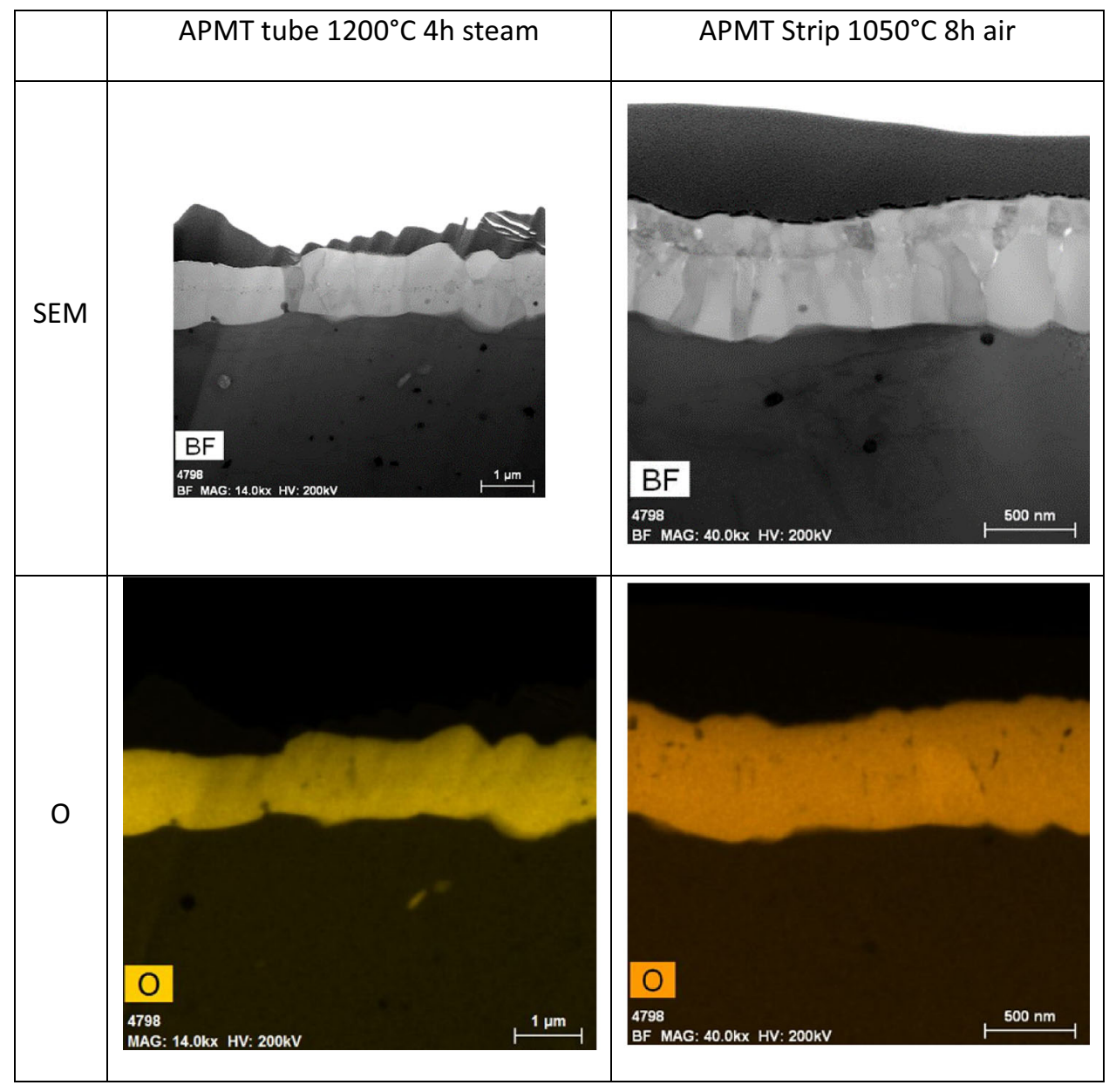

Fig. 6. Alumina oxide layer formed on FeCrAl alloys under exposure to temperatures higher than $1000^{\circ} \mathrm{C}$. 


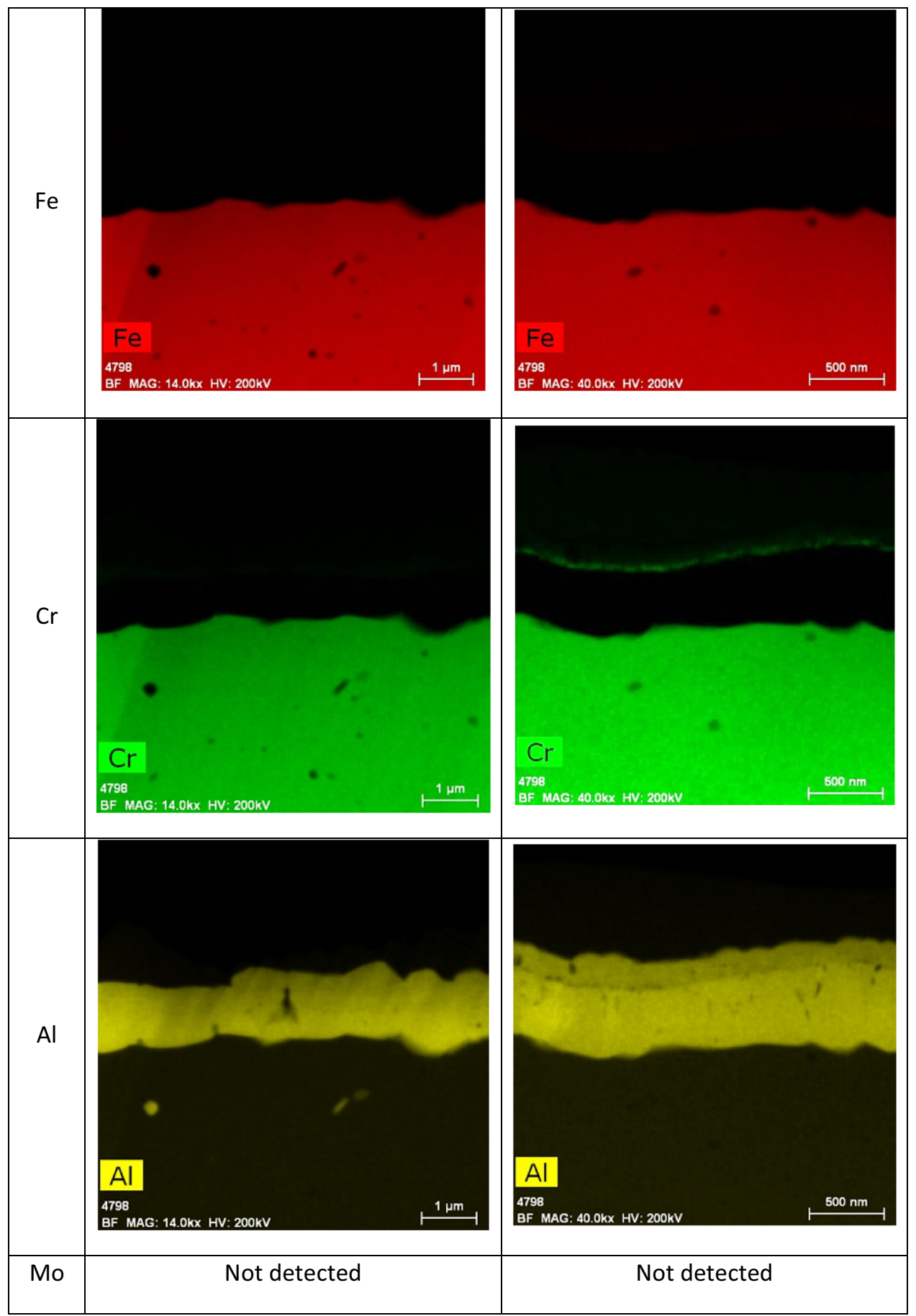

Fig. 6. continued 


\section{Oxides Growth on APMT FeCrAl}

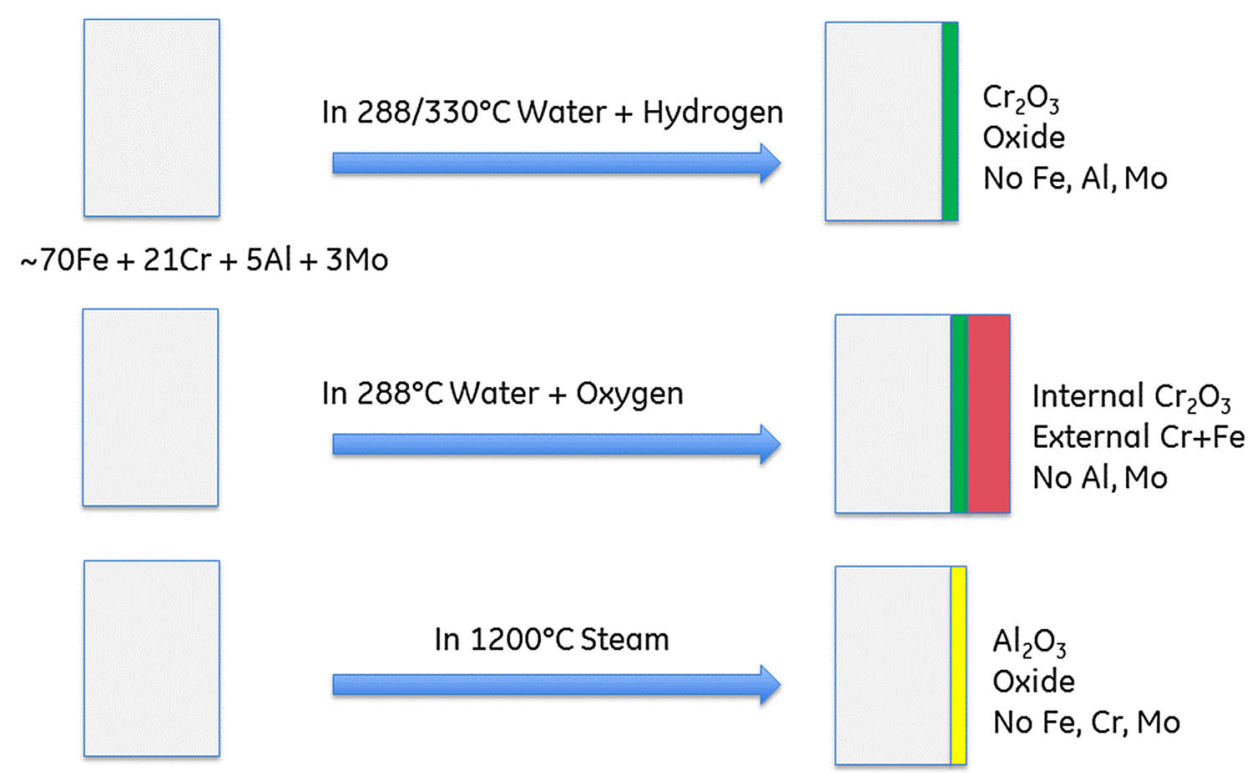

Fig. 7. Schematic representation of the oxides which may develop on FeCrAl alloys under normal operation and accident conditions of a light water reactor.

\section{Question 1: Steam Oxidized APMT Tubes Exposed to High Temperature Water}

Figure 8 shows the mass change (loss) as a function of immersion time for APMT tube specimens exposed to both BWR $\left(288^{\circ} \mathrm{C}\right)$ and PWR $\left(330^{\circ} \mathrm{C}\right)$ hydrogenated water. Each point is the average value for two or more specimens. The mass loss for the $A R$ tube specimens was the same as for the AR flat specimens (Figs. 3 and 8). The tube specimens which were pre-oxidized (PO) in steam initially had a higher mass change (loss) than the tube specimens which were as-received (AR). However, once the alumina layer dissolved in the water, the mass loss of the PO specimens practically stopped, and the mass loss rate became the same as for the AR specimens. The surface area of each PO specimen tube in Fig. 8 was approximately $3.7 \mathrm{~cm}^{2}$. When pre-oxidized in steam at $1200^{\circ} \mathrm{C}$ for $2 \mathrm{~h}$, the tube specimens developed a $1-\mu \mathrm{m}$-thick alumina layer on the surface (Fig. 6). The volume of the alumina layer is $3.7 \mathrm{~cm}^{2} \times 0.0001 \mathrm{~cm}=0.00037 \mathrm{~cm}^{3}$ (volume of aluminum oxide). The mass of aluminum oxide is $\mathrm{m}=\mathrm{V} \times$ density alumina $=0.00037 \times$ $3.95 \mathrm{~g} / \mathrm{cm}^{3}=1.46 \mathrm{mg}$. Dividing the mass of $1.46 \mathrm{mg}$ by the surface area of $3.7 \mathrm{~cm}^{2}=0.4 \mathrm{mg} /$ $\mathrm{cm}^{2}$, which is exactly what the Fig. 8 plot shows as the mass loss of the PO tube specimens due to the dissolution of the alumina layer. This is a clear proof that the initial higher mass change is just the dissolution of the alumina, and then the dissolution stops because a $\mathrm{Cr}_{2} \mathrm{O}_{3}$ should develop on the surface.

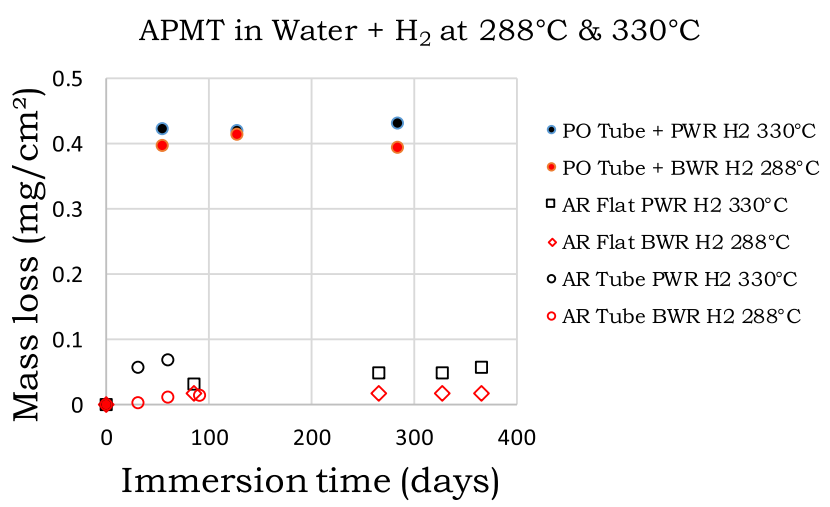

Fig. 8. Mass change (loss) for APMT tube specimens immersed in hydrogenated BWR and PWR water. The open symbols show asreceived $(A R)$ specimens and the closed symbols pre-oxidized $(P O)$ specimens. The round symbols are tube specimens and the square and diamond symbols are flat specimens. The specimens that contained an alumina layer on the surface initially had a higher mass loss, due to the dissolution of the alumina in the hot water.

Figure 9 shows the oxide composition formed on the surface of a APMT tube specimen after immersion in PWR hydrogenated water at $330^{\circ} \mathrm{C}$ for 284 days. These tube specimens were originally pre-oxidized in steam at $1200^{\circ} \mathrm{C}$ for $2 \mathrm{~h}$, that is, they originally contained a $1-\mu \mathrm{m}$-thick alumina layer on the surface (Figs. 6 and 8). Figure 9 shows that the alumina layer from the surface of the preoxidized tube specimen dissolved in water and that a chromium-rich oxide developed, similarly as for a specimen which is as-prepared (not pre-oxidized) (Fig. 5). 


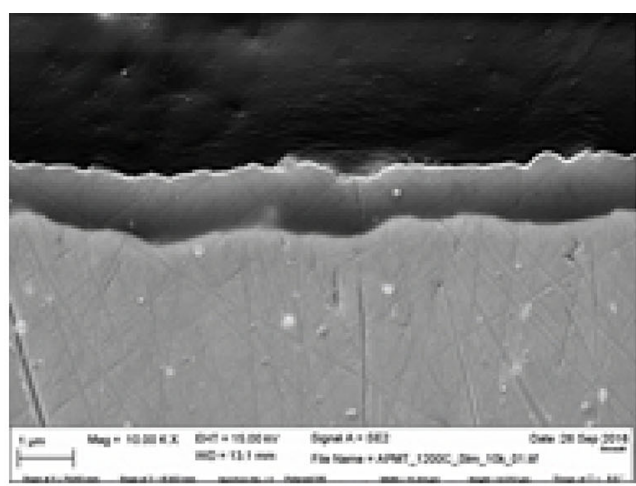

a

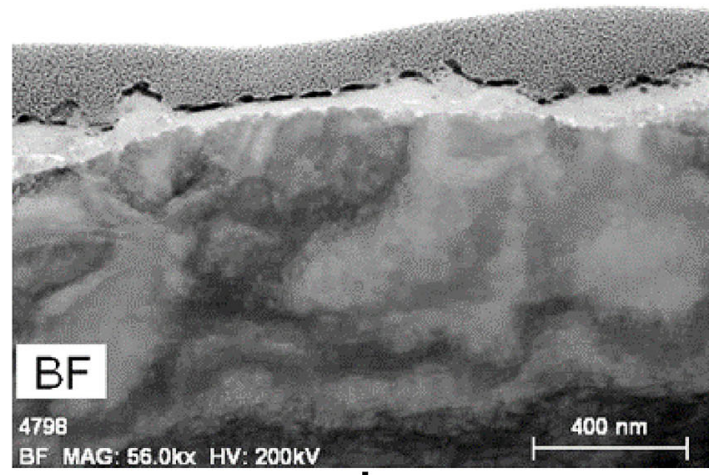

b

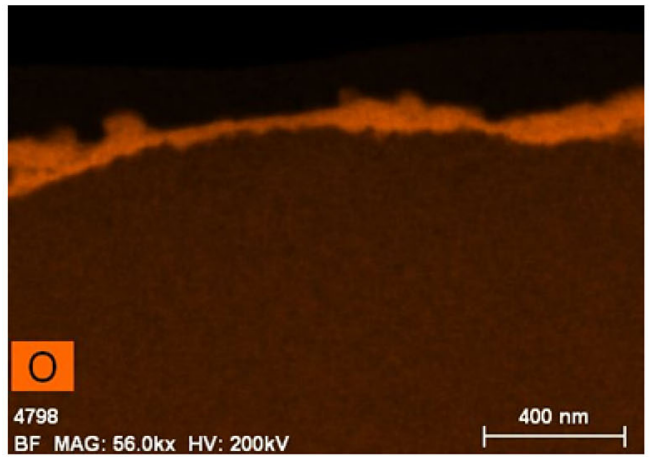

C

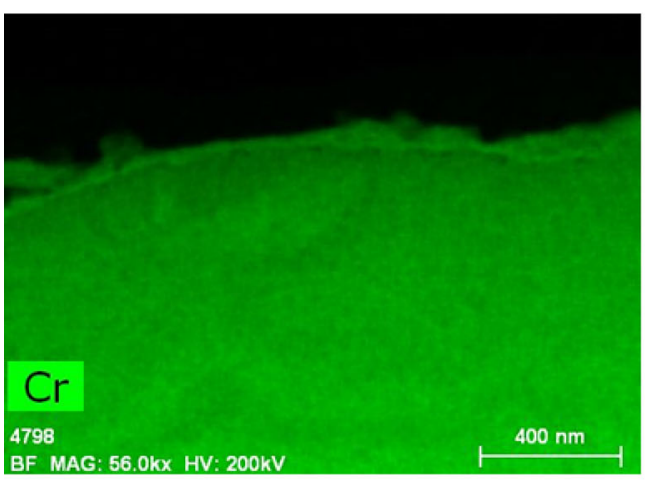

d

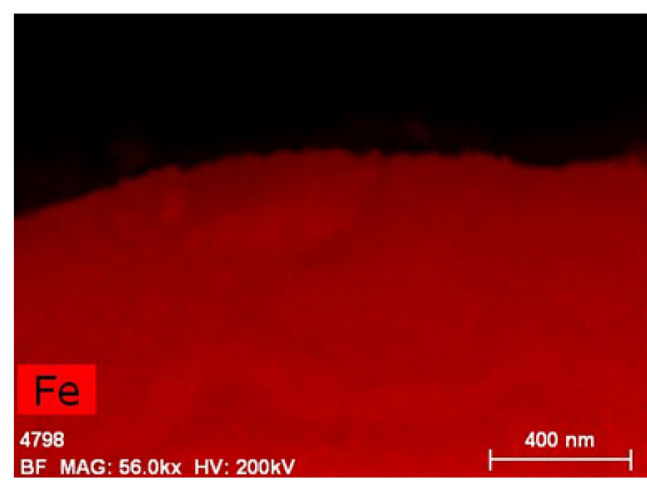

e

Fig. 9. One- $\mu \mathrm{m}$-thick alumina layer in the steam pre-oxidized APMT tube specimens before and after testing in high-temperature hydrogenated water. The alumina layer dissolved from the surface of the specimens and a chromium rich oxide formed to protect the alloy against corrosion. (a) Before immersion in PWR water at $330^{\circ} \mathrm{C}$. The oxide is $1-\mu \mathrm{m}$-thick alumina. (b-e) After immersion in PWR water at $330^{\circ} \mathrm{C}$ for 284 days. The alumina dissolved in the water and a 100-nm-thick layer of chromia formed on the surface.

\section{Question 2: Water Oxidized APMT Tubes Exposed to Superheated Steam}

Figure 10 shows the oxidation resistance for $4 \mathrm{~h}$ in superheated steam at $1200^{\circ} \mathrm{C}$ of the APMT tube specimens, both AR and pre-exposed to high-temperature water for 73 days. Figure 10 shows that specimens which were immersed in high-temperature water for 73 days had the same resistance to superheated steam as fresh AR specimens. That is, fuel rods clad with $\mathrm{FeCrAl}$ alloys in an operating plant will resist attack by superheated steam in the unlikely event of a LOCA. For both the AR tube specimens and for specimens pre-exposed to hightemperature water, the oxidation rate in superheated steam was in the order of $0.25-0.35 \mathrm{mg} / \mathrm{cm}^{2}$.

Figure 11 shows schematically the evolution of the oxides on the surface of FeCrAl alloys from water to steam and steam to water. The alloy was designed with the versatility to develop a protective oxide in each situation. 


\section{DISCUSSION}

Stainless steels (e.g., austenitic type 304 SS) contain at least $13 \%$ of chromium so they can offer passivity in most industrial applications. The longlasting passivity is a slowing down of the corrosion rate of the steel by the formation of a thin protective and adherent layer of chromium oxide on the surface. The passivity provided by chromium oxide of the stainless steels and nickel-based alloys also applies to $\mathrm{FeCrAl}$ alloys in light water reactor environments at temperatures near $300^{\circ} \mathrm{C} .^{9}$ Nuclear power reactors have been successfully

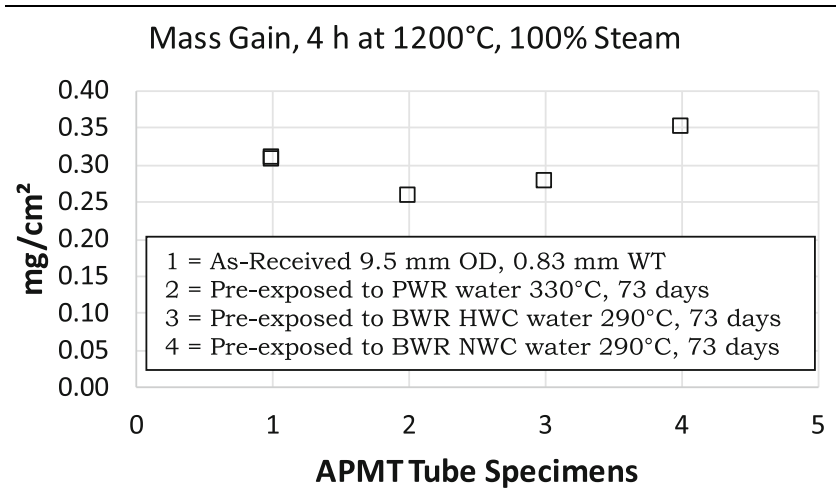

Fig. 10. Oxidation resistance of APMT tube specimens in superheated steam at $1200^{\circ} \mathrm{C}$. The oxidation resistance is the same for as-prepared fresh tubes as for tubes that were exposed to water environments for up to 73 days. That is, in a case of an accident, a FeCrAl tube in the water will develop a protective alumina layer. using stainless steels and nickel alloys with chromium in hot water for over 60 years. Chromium is the element that provides the resistance in hot water by the formation of a protective oxide film on the surface. ${ }^{6,9,10}$

Since 2012, it has been proposed to use ferritic $\mathrm{FeCrAl}$ alloys as an alternative for fuel cladding so they can provide resistance to a severe accident situation. ${ }^{11,12}$ Ferritic FeCrAl alloys have never been used in light water reactors before. The $\mathrm{FeCrAl}$ also contain chromium and it was expected and shown here and elsewhere that they will also develop a thin chromium oxide on the surface to protect against high-temperature water attack. $\mathrm{FeCrAl}$ alloys also have about $4-6 \%$ of aluminum which will "act" only in the case of a severe accident. If a plant never has an accident, the aluminum will just sit and wait. It does not participate in the passive film formed in high-temperature water. Aluminum may never be needed since, for the normal operation conditions, only the chromium is needed. However, we have also shown here that if an unlikely LOCA happens, the aluminum will form the protective alumina layer required to resist the attack by steam. Chromium can protect the cladding tubes against steam only until near $1100^{\circ} \mathrm{C}$. At higher temperatures, aluminum offers the protection to the tubes until their melting point. The synergistic effect between $\mathrm{Cr}$ and $\mathrm{Al}$ in $\mathrm{FeCrAl}$ makes this material ideal for both situations, normal operation conditions and ready in the case of an accident condition.

\section{Oxide Evolution on APMT FeCrAl}

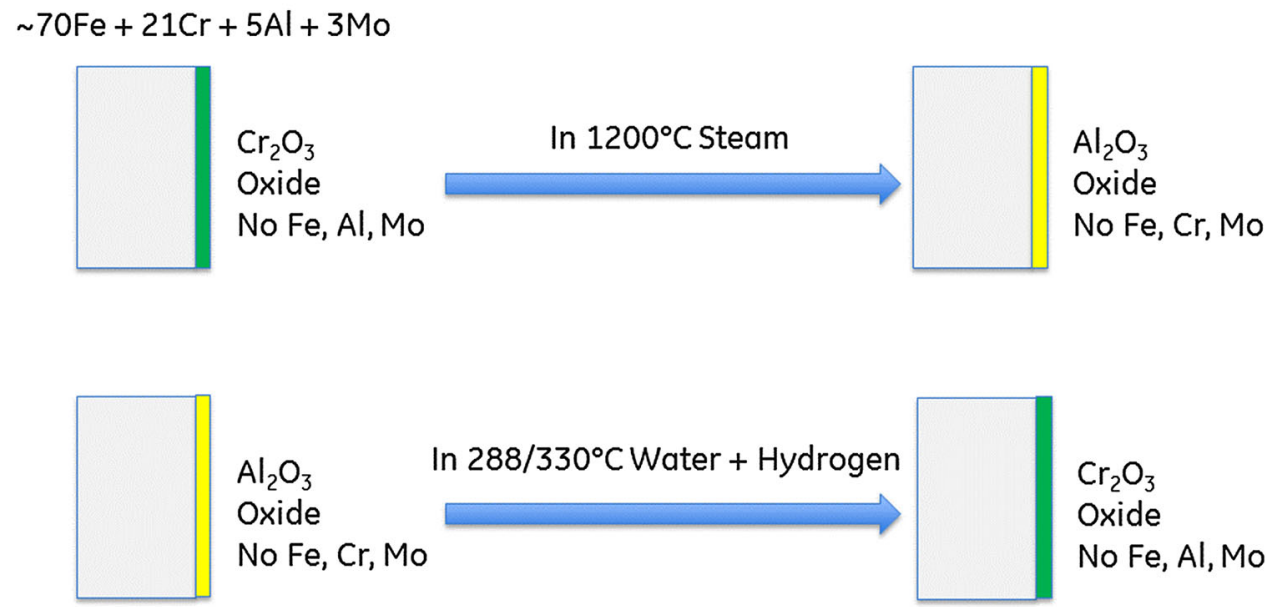

Fig. 11. Schematic representation of the oxides evolution on FeCrAl alloys under normal operation and accident conditions of a light water reactor. 


\section{CONCLUSION}

1. Iron-chrome-aluminum alloys $(\mathrm{FeCrAl})$ contain both $\mathrm{Cr}$ and $\mathrm{Al}$ making it an ideal material to replace zirconium in light water reactors' fuel claddings. $\mathrm{Cr}$ protects the alloy under normal operation conditions and $\mathrm{Al}$ protects the alloy at temperatures higher than $1100^{\circ} \mathrm{C}$.

2. Under normal operation conditions, in a hydrogenated water environment, a thin layer of $\mathrm{Cr}$ oxide forms on the surface of the alloy slowing down the degradation process. Under oxidizing conditions, a dual layer may form. The inner layer is the protective layer of $\mathrm{Cr}$ oxide.

3. If the FeCrAl tube has an alumina layer on the surface, it will dissolve in high-temperature $\left(\sim 300^{\circ} \mathrm{C}\right)$ water and a protective $\mathrm{Cr}$ oxide will form in its place.

4. If a FeCrAl tube has a $\mathrm{Cr}$ oxide on the surface and it is exposed to accident steam conditions, the $\mathrm{Cr}$ oxide layer will evaporate and an alumina layer will form to protect the tube.

\section{ACKNOWLEDGEMENTS}

This material is based upon work supported by the Dept. of Energy (National Nuclear Security Administration) under Award Number DENE0008221. This report was prepared as an account of work sponsored by an agency of the United States Government. Neither the United States Government nor any agency thereof, nor any of their employees makes any warranty, express or implied, or assumes any legal liability or responsibility for the accuracy, completeness, or usefulness of any information, apparatus, product, or process disclosed, or represents that its use would not infringe privately owned rights. Reference herein to any specific commercial product, process or service by trade name, trademark, manufacturer, or otherwise does not necessarily constitute or imply its endorsement, recommendation, or favoring by the United States Government or any agency thereof. The views and opinions of authors expressed herein do not necessarily state or reflect those of the United States Government or any agency thereof.

\section{OPEN ACCESS}

This article is distributed under the terms of the Creative Commons Attribution 4.0 International License (http://creativecommons.org/licenses/by/4.0/), which permits unrestricted use, distribution, and reproduction in any medium, provided you give appropriate credit to the original author(s) and the source, provide a link to the Creative Commons license, and indicate if changes were made.

\section{REFERENCES}

1. International Energy Outlook 2016. (US Energy Information Administration, 2016), https://www.eia.gov/todayine nergy/detail.php?id=26212. Retrieved 18 Aug 2017.

2. M. Korsnick, in press conference 20 Oct 2016 (Nuclear Energy Institute), www.nei.org/News-Media.

3. IAEA (International Atomic Energy Agency), PRIS (Power Reactor Information System), www.iaea.org.

4. J. Tollefson, Nature 537, 16 (2016).

5. C. Tang, M. Stueber, H.J. Seifert, and M. Steinbrueck, Corros. Rev. 35, 141 (2017).

6. F. Nagase, K. Sakamoto, and S. Yamashita, Corros. Rev. 35,129 (2017).

7. R.B. Rebak, W.P. Gassmann, and K.A. Terrani, in Paper A0042, IAEA, Top Safe 2017 conference, 12-16 February 2017, Vienna, Austria.

8. S.M. Bragg-Sitton, M. Todosow, R. Montgomery, C.R. Stanek, R. Montgomery, and W.J. Carmack, Nucl. Technol. 195, 111 (2016)

9. K.A. Terrani, B.A. Pint, Y.-J. Kim, K.A. Unocic, Y. Yang, C.M. Silva, H.M. Meyer III, and R.B. Rebak, J. Nucl. Mater. 479,36 (2016).

10. R.B. Rebak, M. Larsen, and Y.-J. Kim, Corros. Rev. 35, 177 (2017).

11. R.B. Rebak, Metall. Trans. E 2, 197 (2015).

12. K. Sakamoto, M. Hirai, S. Ukai, A. Kimura, A. Yamaji, K. Kusagaya, T. Kondo, and S. Yamashita, in WRFPM 2017 Conference (Jeju Island, September, 2017). 